\title{
Yeasts and wine off-flavours: a technological perspective
}

\author{
Manuel Malfeito-Ferreira
}

Received: 10 February 2010 / Accepted: 7 July 2010

(C) Springer-Verlag and the University of Milan 2010

\begin{abstract}
In wine production, yeasts have both beneficial and detrimental activities. Saccharomyces cerevisiae is the yeast mainly responsible for turning grape juice into wine but this species and several others may also show undesirable effects in wines. Among such effects, technologists are particularly concerned with the production of offflavours that may occur during all stages of winemaking. Typical spoiling activities include the production of ethyl acetate by apiculate yeasts before fermentation, hydrogen sulphide by $S$. cerevisiae during fermentation phases, acetaldehyde by film-forming yeasts during bulk storage, and volatile phenols by Dekkera bruxellensis during storage or after bottling. The occurrence of these hazards depends on the technological operations designed to obtain a given type of wine and most can be avoided by current preventive or curative measures. On the contrary, good manufacturing practices must be strengthened to deal with the problem of volatile phenol production in red wines. Appropriate monitoring of $D$. bruxellensis populations and quantification of 4-ethylphenol is advised during storage, particularly when oak barrels are used, and absence of viable cells must be guaranteed in bottled wines. This work, which is based on our experience at winery level, aims to provide information on appropriate technological strategies to deal with the problem of off-flavours produced by yeasts.
\end{abstract}

This paper is part of the special issue "Wine microbiology and safety: from the vineyard to the bottle (Microsafetywine)", 19-20 November 2009, Martina Franca (Italy).

M. Malfeito-Ferreira $(\bowtie)$

Laboratório de Microbiologia, Centro de Botânica Aplicada à

Agricultura, Instituto Superior de Agronomia,

Technical University of Lisbon,

Tapada da Ajuda,

1349-017 Lisbon, Portugal

e-mail: mmalfeito@isa.utl.pt
Keywords Wine · Yeasts · Spoilage · Dekkera bruxellensis . Volatile phenols

\section{Introduction}

Wine is the product of grape juice fermentation, mostly by the yeast Saccharomyces cerevisiae. The technological process involves a wide range of yeast species making different contributions to wine quality. Many are occasional contaminants of equipment or are carried by grapes into the winery and have no obvious role in winemaking. On the contrary, other species, known as spoilage yeasts, are a permanent concern due to their possible detrimental effects. Specifically, sensu stricto spoilage yeasts are able to adversely modify foods processed according to the standards of good manufacturing practice (GMP) and include species resistant to the stresses provoked by food or beverage processing (Pitt and Hocking 1985; Loureiro and Querol 1999).

The most commonly recognised symptoms of yeast spoilage are film formation in bulk wines, cloudiness, sediment formation and gas production in bottled wines, and off-flavour production during all processing and storing stages (Loureiro and Malfeito-Ferreira 2003). The latter is hard to define because microbial metabolites contribute to wine flavour, and their pleasantness or otherwise, besides being dependent on their concentration, is driven by many subjective factors (e.g. habit, fashion, opinion makers' choices) that influence consumer taste. Therefore the definition of spoilage as "the alteration of food recognised by the consumer" (Stratford 2006) is not fully satisfactory for wines. This situation is clearly demonstrated by the presence in red wines of volatile phenols produced by the species Dekkera bruxellensis. While some consumers and 
opinion makers prefer wines tainted by volatile phenols, others consider that, even at low concentrations, these compounds depreciate wine quality due to diminished flavour complexity.

The purpose of this review is to describe the most common technological problems associated with offflavours produced by yeasts in wines and to propose preventive control measures.

\section{Description of the main yeast genera/species involved in wine spoilage}

Species involved in wine spoilage are also known to affect other food commodities, and their taxonomical, physiological and technological properties have been described in several excellent textbooks (Deak and Beuchat 1996; Boekhout and Robert 2003; Blackburn 2006; Querol and Fleet 2006). The description of the species presented below concerns mainly their role in hazards related to wine offflavours (Table 1).

Apiculate yeasts

Apiculate yeasts, which owe their denomination to their lemon-shaped form, include species of the genera Kloeckera/Hanseniaspora. These are particularly frequent on grape surfaces and in juices after grape crushing (Fleet et al. 2002). These species are controlled easily by adequate winemaking measures (low temperature, sulphur dioxide, hygiene) and are inhibited during fermentation. The production of unwanted amounts of metabolites such as ethyl acetate (causing vinegar smell) (Romano 2005) may occur in white juices with long settling periods or with long skin contact and in long red pre-fermentative maceration. This spoilage activity is due to their fast growth but is not a great concern to enologists because preventive measures can be easily implemented.

Film-forming species

The denomination "film-forming yeasts" includes a group of species able to grow on the surface of wine, developing pellicles. Species of the genus Candida and Pichia are regarded as typical film-forming yeasts although $S$. cerevisiae, D. bruxellensis or Zygosaccharomyces bailii may also be recovered from wine pellicles (Ibeas et al. 1996; Farris et al. 2002). In the case of $S$. cerevisiae, pellicles production is even a desirable feature for the race beticus, which is one of the agents of sherry-type wine production (Suárez-Lepe and Iñigo-Leal 2004). The ability to form films by Pichia and Candida is probably explained by their aerobic nature and fast growth, and so other species are usually only minor constituents of film microflora. In bulk wines, these yeasts, which quickly cover the wine surface when air has not been removed from the top of storage

Table 1 Most common hazards due to off-flavours produced by yeasts in wines

\begin{tabular}{|c|c|c|c|}
\hline Production stage & Hazard & $\begin{array}{l}\text { Main preventative and } \\
\text { curative action }\end{array}$ & Frequency \\
\hline Rotten grapes & $\begin{array}{l}\text { Primary source of spoilage } \\
\text { yeasts } \\
\text { Increased volatile acidity and } \\
\text { other off-flavours }\end{array}$ & $\begin{array}{l}\text { Prevention of damage in } \\
\text { the vineyard } \\
\text { Grape selection at winery } \\
\text { reception }\end{array}$ & $\begin{array}{l}\text { Low/high (dependent on } \\
\text { weather conditions) }\end{array}$ \\
\hline Grape juice & $\begin{array}{l}\text { Production of ethyl acetate by } \\
\text { apiculate yeasts }\end{array}$ & $\begin{array}{l}\text { Low temperature } \\
\text { Adequate sulphite dose }\end{array}$ & Low \\
\hline Fermentation & $\begin{array}{l}\text { Production of hydrogen sulphide } \\
\text { by Saccharomyes cerevisiae }\end{array}$ & $\begin{array}{l}\text { Control nutritional status } \\
\text { of grape juices } \\
\text { Aeration during fermentation } \\
\text { Post-fermentation curative processes }\end{array}$ & Moderate/high \\
\hline Bulk wine storage & $\begin{array}{l}\text { Production of acetaldehyde by } \\
\text { film-forming yeasts }\end{array}$ & $\begin{array}{l}\text { Tank topping } \\
\text { Minimisation of oxygen } \\
\text { contact } \\
\text { Adequate sulphite dose }\end{array}$ & Low \\
\hline $\begin{array}{l}\text { Wine storage (tank, } \\
\text { barrique, bottle) }\end{array}$ & $\begin{array}{l}\text { Production of volatile phenols } \\
\text { by Dekkera bruxellensis }\end{array}$ & $\begin{array}{l}\text { Adequate preservative dose } \\
\text { Filtration/thermal treatment } \\
\text { Minimisation of oxygen } \\
\text { contact } \\
\text { Prevention of cross } \\
\text { contamination } \\
\text { Barrique hygiene }\end{array}$ & Medium/high \\
\hline
\end{tabular}


vessels, produce acetaldehyde, which imparts an oxidised (bruised apple) aroma. Although this not a frequent occurrence, it may affect young red wines before malolactic fermentation when sulphite levels are low and tanks are not topped. Although strains of Candida spp. or Pichia spp. may be tolerant to preservatives (Table 2), their control in wines is achieved mainly through their weak tolerance to low oxygen tensions, which enhances the inhibitory effect of ethanol or preservatives to be used. In bottled wines, these yeasts may cause sediments if the initial contamination load is high; thus these species are regarded as indicators of poor GMP (Loureiro and Malfeito-Ferreira 2003). They may also produce a film or a ring of cells adherent to the glass at the bottleneck if the closure does not prevent the diffusion of oxygen, the level of free sulphur dioxide is too low and the initial contamination level is high.

Fermenting yeasts

Saccharomyces cerevisiae and Saccharomyces bayanus are the desired agents of wine fermentation. However, they may also be responsible for wine spoilage. During fermentation, an occasional nutritional imbalance in the grape juice may lead to off-flavour production imparted by reduced sulphur compounds (Bell and Henschke 2005). Modern winemaking systems, with juice pumped under anaerobic conditions, tend to increase the problem, in contrast to older systems where juice aeration was present. If not treated in time, these taints may persist during storage and in bottled wines.

Volatile phenols (vinylphenols) imparting medicinal offflavours may be produced by $S$. cerevisiae due to decarboxylation of free hydroxycinnmaic acids released by the commercial pectolytic enzymes used to clarify grape juices (Dugelay et al. 1993). This hazard is not common at present due to improvements in the purity of such enzyme preparations.

Another problem is the inhibition of fermenting yeasts leading to stuck fermentations (Bisson and Butzke 2000). This event is a result of poor environmental conditions (e.g. temperature, lack of grape juice nutrients) and changing yeast metabolism rather than any particular spoilage characteristic. The correct management of fermenting conditions overcomes the problem. Usually, stuck wines have higher volatile acidity but its origin is difficult to determine because it may result from the activity of fermenting yeasts, other contaminating yeasts or bacteria.

\section{Dekkera/Brettanomyces bruxellensis}

Recognition of the role played by the species D. bruxellensis in red wine spoilage due to the production of "horse sweat" taint (due to ethylphenols), in bulk or bottled wines has presented a new challenge to winemakers in the last decade (Loureiro and Malfeito-Ferreira 2006). Moreover, its effects are particularly notorious in high quality red wines aged in costly oak barrels, which have considerably increased the economic losses provoked by spoilage yeasts in the wine industry. Presently, this species is regarded as the main threat posed by yeasts to wine quality. The effect is not only direct, due to the production of volatile phenols, but also indirect due to the technological measures needed to control its activity that may also reduce wine attributes.

Dekkera bruxellensis has long been known as an undesirable contaminant, due to acetic acid production and its "mousy" taint. An unambiguous link between its activity and the ethylphenol taint has been established (Chatonnet et al. 1995, 1997). The present widespread use of oak barrels to age red wines, where the ability to produce ethylphenols overwhelms the presence of other contaminants, has contributed significantly to its notoriety. In

Table 2 Yeast tolerance to antimicrobial agents used in winemaking. $P M B$ Potassium metabisulphite, $D M D C$ dimethyl dicarbonate

\begin{tabular}{|c|c|c|c|c|c|}
\hline Tolerance measure & Agent & D. bruxellensis & Pichia spp. & S. cerevisiae & Reference \\
\hline \multirow[t]{4}{*}{$\begin{array}{l}\text { Maximum concentration } \\
\text { allowing growth }\end{array}$} & Ethanol $(\% \mathrm{v} / \mathrm{v})$ & 15 & $15^{\mathrm{a}}$ & 17 & $\begin{array}{l}\text { Dias et al. }(2003 a, b), \\
\text { Barata et al. }(2006,2008 a)\end{array}$ \\
\hline & PMB (mg/l) & 90 & $140^{\mathrm{a}}$ & 200 & $\begin{array}{l}\text { Dias et al. }(2003 a, b), \\
\text { Barata et al. }(2006,2008 a)\end{array}$ \\
\hline & Total $\mathrm{SO}_{2}(\mathrm{mg} / \mathrm{l})$ & 75 & $350^{\mathrm{b}}$ & 50 & Loureiro (1997) \\
\hline & Sorbic acid (mg/l) & 950 & $650^{\mathrm{b}}$ & 300 & Loureiro (1997) \\
\hline $\begin{array}{l}\text { Minimum concentration } \\
\text { inducing complete death }\end{array}$ & $\mathrm{DMDC}(\mathrm{mg} / \mathrm{l})$ & 100 & $100^{\mathrm{a}}$ & 100 & Costa et al. (2008)) \\
\hline $\begin{array}{l}\text { Maximum concentration } \\
\text { allowing growth }\end{array}$ & $\mathrm{CO}_{2}$ (dissolved volumes) & 4.45 & - & 2.23 & Ison and Gutteridge (1987) \\
\hline
\end{tabular}

\footnotetext{
${ }^{a}$ Pichia guilliermondii
}

${ }^{\mathrm{b}}$ Pichia membranifaciens 
addition, controversy about its influence on wine quality among winemakers, journalists and consumers make this species currently the most prominent subject in the field of microbial wine spoilage.

Dekkera bruxellensis is a rather elusive yeast, being difficult to isolate from sources contaminated by other yeasts due to its low growth rate. Thus the use of selective media and long incubation periods are essential to its recovery. It has been isolated only rarely from grapes (Guerzoni and Marchetti 1987; Renouf and LonvaudFunel 2007) and winery environments (Connel et al. 2002), being dominant in bottled red wines, as a producer of ethylphenols, or in sparkling wines, inducing cloudiness, when there is no concurrence with other yeasts (Loureiro and Malfeito-Ferreira 2006). In relative terms, it is not as tolerant to ethanol or preservatives as $S$. cerevisiae or Z. bailii (Table 2) but has the ability to remain viable for long periods and to proliferate when conditions become less severe (Renouf et al. 2007). The occasional detection of these yeasts in sparkling wines may be related to their resistance to carbon dioxide (Table 2). However, it is seldom isolated from still white wines, which induce cell death under the normal range of ethanol and $\mathrm{pH}$ values (Barata et al. 2008a).

\section{Control of yeast populations in wines}

The enologist can use a wide range of measures to prevent yeast spoiling activities. These comprise inhibitory or lethal agents applied to wine, such as chemical preservatives and thermal treatments. Other physical operations, although not directed to kill microorganisms, have a removal effect, e.g. the operations of clarification, fining or filtration. All control operations must be accompanied by adequate hygienic procedures to prevent wine contamination by yeasts colonising winery surfaces. In addition, it should be kept in mind that wine by itself is a stressful environment. The intrinsic properties of each wine determine the efficiency of each control measure. For instance, a lack of nutrients makes wine less vulnerable to microbial growth and ethanol content increases wine robustness. Likewise, the carbonation used in some types of wines is inhibitory to most yeasts but is not directed primarily at yeast control. With the opposite effect, oxygen may be added to improve wine ageing but it also stimulates yeast growth. Moreover, a major hurdle currently faced by the wine industry is highlighted by the need to decrease the utilisation of sulphur dioxide, which is associated with human allergies and subjected to stricter legal limits. In conclusion, proper management of microbial contaminants is dependent on an integrated approach involving all factors affecting yeast growth.
Hygiene

Stringent hygiene is particularly important after sterile filtration or flash pasteurisation to avoid contamination, or cross-contamination when contaminated wines are pumped during winery operations.

Nevertheless, winemakers are aware that, in practical terms, situations where proper hygiene is not possible occur frequently. Sanitising efficiency decreases from materials like stainless steel, through to concrete, plastic and rubber due to increased surface roughness. The most difficult, or practically impossible, surface to sanitise properly is the wood used for wine maturation. In modern winemaking, oak barrels, which are widely used, particularly for high quality red wines, represent the main difficultly in preventing wine contamination by $D$. bruxellensis. Sanitising agents containing chlorine must be avoided to prevent the formation of the trichloroanisoles responsible for "cork taint". Most common treatments use hot water, sulphite solutions, steam, and ozone as cleaning and disinfecting agents. However, their efficiency is very limited due to the porous nature of the wood. Contamination of the outer layers of the wood may be significantly reduced, but the inner layers, soaked by wine, still harbour yeast populations able to recontaminate wine after sanitation (Laureano et al. 2004). The critical points are the grooves and the surfaces between staves, where the sanitising agents do not reach the microbial cells embedded in the wood. Therefore, recovery of infected barrels must include dismantling and removal of all parts soaked by wine.

\section{Clarification, fining and filtration}

During storage, wines are subjected to several operations directed at the improvement of storage and ageing conditions (Renouf and Lonvaud-Funel 2004). Clarification by settling or centrifugation leads to the reduction of suspended material including microorganisms. High-speed centrifugation can achieve practically sterile wines just after fermentation. Fining agents are usually directed to improve wine organoleptical characteristics by removing microorganisms during wine settling as well. Filtration by diatomaceous earths is currently done during wine ageing and the tightest earths reduce microbial numbers drastically. The correct management of clarification, fining and filtration operations favours the minimisation of chemical or thermal treatments during storage. When wine is ready to bottle, pre-bottling filtration is the most common procedure to achieve wine "sterilisation". Several types of filtering media may be used, depending on the winemakers' choice, but the ultimate goal is to prevent microbial growth in bottled wines. If coarser pore sizes are used, higher levels of wine stabilising treatments should be used. Some wines, 
particularly stylish red wines, may not be filtered or pasteurised due to claimed quality constraints, and so require a higher dose of preservatives to avoid microbial development in the bottled product. However, in our experience, these unfiltered or coarsely filtered wines are those most frequently affected by "horse sweat taint" and by refermentation in the bottle.

\section{Oxygen and storage temperature}

Spoilage yeasts are facultative anerobes that are stimulated by small amounts of oxygen. The effect of air in contact with wine is well known by the winemaker. If vessels are not topped a microbial film develops at the wine surface together with the development of an oxidised taint due to acetaldehyde formation, as described above. However, low amounts of oxygen are required for wine maturation, especially for red wines, which have led to the development of so-called "micro-oxygenation" processes. Therefore, adequate management of all operations introducing oxygen in wine is required to minimise spoilage yeast growth. Inadequate bottling machines may introduce oxygen in bottled wine, which stimulates yeast growth exponentially (Malfeito-Ferreira et al. 1990). In oak barriques, oxygen diffuses continuously up to $30 \mathrm{mg} \mathrm{l}^{-1}$ year $^{-1}$ through the wood (Ribéreau-Gayon et al. 2006) and stimulates growth of D. bruxellensis (Malfeito-Ferreira et al. 2001; du Toit et al. 2006). Unadjusted cork jaws may affect corks, providing channels of air into the bottled wine, reducing free sulphur dioxide and stimulating yeast growth.

Storage at low temperatures (naturally cooled or refrigerated cellars) acts by delaying microbial growth but should not be regarded as a lethal agent, because most microorganisms grow when the temperature increases.

\section{Chemical preservatives}

In winery practice, the control of microbial populations depends most effectively on the maintenance of adequate levels of sulphur dioxide. In wines, this agent is present either in the free or combined form. The active form is molecular sulphite, which is calculated by multiplying the free amount by the proportion of molecular sulphite as a function of $\mathrm{pH}$. However, sulphur dioxide cannot be added continuously because it is subject to maximum legal limits. In the EU, these limits are a function of wine type (Loureiro and Malfeito-Ferreira 2003), while in the US the maximum level of total sulphite is $350 \mathrm{mg} / \mathrm{l}$ (Fugelsang and Edwards 2007). After addition, a fraction of the sulphite is combined and loses its antimicrobial activity. All conditions leading to sulphite combination must be minimised. The use of high doses of sulphur dioxide before fermentation can increase the production of acetaldehyde by fermenting yeasts. The combination rate may be $50 \%$ or more of the added amount. Therefore additions should be controlled by sulphite measurement after treatment. To prevent microbial growth, common advised levels are $0.5-0.8 \mathrm{mg} / 1$ molecular sulphur dioxide (Fugelsang and Edwards 2007) but yeasts vary in their resistance to this preservative (Table 2). In addition, growing populations are more resistant, $1 \mathrm{mg} / \mathrm{l}$ molecular sulphite being required to prevent the proliferation of D. bruxellensis (Barata et al. 2008a).

Sorbic acid is a weak acid, the free form of which is present in higher proportions at lower $\mathrm{pH}$ values. The maximum legal limits are $200 \mathrm{mg} / 1$ in the $\mathrm{EU}$ and $300 \mathrm{mg} / \mathrm{l}$ in the US (Fugelsang and Edwards 2007). Due to its higher solubility, potassium sorbate is used as the vehicle of sorbic acid. Its usage is advised, together with sulphur dioxide, at bottling of sweet wines to inhibit fermentating yeasts. It is metabolised by lactic acid bacteria, originating the "geranium taint". At the maximum legal doses it is not effective against $D$. bruxellensis (Table 2).

Dimethyl dicarbonate (DMDC) has been recently approved in the EU for use at the maximum amount of $200 \mathrm{mg} / \mathrm{l}$ at bottling of wines with more than $5 \mathrm{~g} / \mathrm{l}$ residual sugar. In the US it may be used during the storage of wine in regular amounts up to the maximum level of $200 \mathrm{mg} / \mathrm{l}$ (Fugelsang and Edwards 2007). Its efficiency depends on the initial microbial contamination, with a maximum of 500 viable cells $/ \mathrm{ml}$ wine being advised. Yeasts vary in their susceptibility to DMDC (Daudt and Ough 1980; Costa et al. 2008). Bacteria are more resistant than yeasts and so this preservative should not be regarded as a sterilant when used alone (Costa et al. 2008). Therefore, in wineries, if legally authorised, DMDC should be used routinely together with sulphite during wine storage or at bottling. Its activity depends on adequate homogenisation, which is achieved by a costly dosing apparatus. Another factor requiring precautions is its human toxicity (Fugelsang and Edwards 2007).

\section{Thermal treatments}

Several thermal treatments may be applied in wine processing with or without any deliberate effect on microorganisms. Wine refrigeration may reduce microbial loads but the aim is to stabilize bitartrates and microbes are removed in the process. Thermovinification consists of heating crushed red grapes and separating the heavily coloured juice to be fermented without maceration (Ribéreau-Gayon et al. 2006). The purpose here is to extract colouring matter not to destroy contaminant microbiota. However, in the case of spoilage yeasts, this technique is especially appropriate for processing rotten grapes because it kills all contaminating microorganisms and enables fermentations dominated by $S$. cerevisiae. 
Surprisingly, in contrast to other beverage industries (beer, juices, and soft drinks), heat treatments are rarely used in the wine industry. In particular, heat treatments should be included among current options, mainly for wines with residual sugar. In flash pasteurisation the wine is heated and cooled in plate exchangers and may be sterile filtered before bottling to avoid recontamination. In hot bottling, or thermolisation, wine is heated and bottled at the desired temperature, being cooled after bottling (Humbert 1980). Wine microorganisms are heat sensitive and so relatively mild temperatures are enough to ensure product sterilisation (Devéze and Ribéreau-Gayon 1977; Barata et al. 2008b). However, winemakers are generally reluctant to use heat treatments due to claimed deleterious effects on wine organoleptical quality and longevity.

\section{Yeast monitoring}

Microbiological control

The practical absence of microbiological safety hazards in the wine industry have meant that Hazard Analysis Critical Control Point (HACCP) and self-control plans, which are mandatory in food industries, are not implemented with the desirable strictness. In fact, the microbial stability of most dry table wines-white, rosé or red-attained when good winery practices are followed, leads to the absence of microbiological control by most producers. Exceptionally, commercial contracts with modern distributors (supermarket chains and others) or demanding clients may force the implementation of routine microbiological analysis.

Recently, at least two hazards of microbiological origin were identified in wines: mycotoxins, such as the Ochratoxin A that is produced by Aspergillus ochraceus and Penicillium verrucosum in mouldy grapes; and biogenic amines, normally associated with the development of malolactic bacteria belonging to Oenococcus, Pediococcus and Lactobacillus genera, occurring after the alcoholic fermentation. The formation of biogenic amines in wine from Brettanomyces was first observed by Caruso et al. (2002), who detected $10 \mathrm{mg} / \mathrm{l}$ phenylethylamine on average. Some authors (Vigentini et al. 2008; Agnolucci et al. 2009) have recently also noted this phenomenon and confirmed the ability of some strains of $D$. bruxellensis to produce detectable amounts of cadaverine, hexylamine, phenylethylamine, putrescine and spermidine, under winemodel conditions. However, these hazards are not assessed in routine microbiological control because, in general, their risk of occurrence is rather low (Malfeito-Ferreira et al. 2009).

\section{Grape and grape juice monitoring}

During wine fermentation it is neither easy nor justifiable to implement microbiological control plans to detect spoilage yeasts. Their influence in wine quality, as a rule, is irrelevant, and possible corrective measures are practically absent. One of the few measures is to establish chemical indicators related with grape microbiological quality, which are already implemented in numerous wineries (particularly cooperatives or large companies to establish the price of grapes as a function of its health status) like laccase activity (indicator of grapes affected by grey rot) or volatile acidity and gluconic acid (indicator of grapes affected by sour rot). The utilisation of costly Fourier transform infrared (FTIR) instruments makes these determinations readily available, thus providing the possibility of separate processing according to raw material quality. In smaller scale wineries, grape selection enables the removal or separate processing of poor quality grapes.

\section{Bulk wine monitoring}

After wine fermentation, most wineries measure qualitative or quantitative chemical indicators to control the activity of lactic acid bacteria (malic acid assessment) and acetic acid bacteria (volatile acidity). It is not current practice to monitor the presence of spoilage yeasts. However, it would be useful to screen spoilage yeasts or their secondary metabolites, such as 4-ethylphenol, acetaldehyde and ethyl acetate, especially in wines produced from grapes of poor sanitary quality. In this case, the prevalence of such yeasts seems to be high and wine resistance to microbial colonisation is reduced, creating conditions conducive to product alteration. During this stage it is also important to monitor the presence of film-forming yeasts growing on the wine surface, mainly in large volume vessels or untopped tanks where it is not easy to avoid the presence of oxygen required by these yeasts. Microbiological analysis is not a requirement but visual inspection of tank tops every 2 weeks is a simple and effective practice.

\section{Wine bottling}

Wine bottling is the main processing stage where conventional microbiological control should be adopted by wineries. Common procedures include analysis of bottles, rinsing water, closures (corks, rip caps), bottling and corking machines and atmosphere. When properly applied this control enables the detection of contamination sources. Most frequently, these sources are located in the filling and corking machines. After bottling, common microbial contaminants do not survive for long. Then, if microbial counts are higher than those specified, the product is retained until clearance is given (Loureiro and Malfeito-Ferreira 2003). 


\section{The change of paradigm by D. bruxellensis}

The relatively low-demand microbiological control in wineries is no longer advisable for red wines, particularly those requiring appropriate aging. Presently, the detection of $D$. bruxellensis is a pre-requisite for wineries during all processing stages of high quality red wines. In fact, it frequently appears in high levels just after the malolactic fermentation (Rodrigues et al. 2001), leading to premature "horse sweat" taint. During barrel ageing it is essential to monitor D. bruxellensis periodically, especially in used barrels, which are a well known ecological niche of these yeasts. For many Portuguese wineries, we have established microbiological criteria that have been giving adequate results so far, and are given here only as guidelines. In the first case, for bulk-stored wines, it is satisfactory to detect D. bruxellensis monthly, bimonthly or even every 3 months (according to the type of wine and container). The sample volumes are $1,0.1,0.01$ and $0.001 \mathrm{ml}$, from a blend composed of wine from the interface air/liquid and from different depths of the container. When the result is positive for $1 \mathrm{ml}$, or less, and the level of 4-ethylphenol is higher than $150 \mu \mathrm{g} / \mathrm{l}$, it is recommended that a fine filtration be applied immediately, accompanied by sulphite addition. In subsequent analysis after filtration, it is sufficient, as a rule, to monitor the level of 4-ethylphenol. The criteria are more stringent for wines before bottling, and detection should be made on 100, 10 and $1 \mathrm{ml}$ wine, sampled as described above. When the result is positive in 1 or $10 \mathrm{ml}$, a very fine or sterilizing filtration is recommended. If positive detection is obtained only for $100 \mathrm{ml}$, it is acceptable to control viable cells only by addition of preservatives (e.g. $1 \mathrm{mg} / \mathrm{l} \mathrm{molecular}$ sulphite). In this case, bottling must be technically correct and dissolved oxygen should be lowered to practically zero. Otherwise, a sterile filtration is recommended or, as an alternative, a light heat treatment of the wine to destroy viable cells. Absence of $D$. bruxellensis should be checked regularly during storage because one viable cell per bottle may spoil the product if enough time is provided for it to grow (Barata et al. 2008a, b).

\section{Microbiological control methods}

As a rule, yeast detection and enumeration methodologies are based on growth on plates containing a general-purpose culture medium, after membrane filtration of wine samples or rinsing solutions (Loureiro et al. 2004). The use of the most probable number (MPN) technique is not common but, according to our practical experience, would be useful in some situations, particularly in wines with a high percentage of suspended solids or when moulds may cover the agar plates.
The utilisation of selective and/or differential culture media has increased slightly in the last few years, owing mainly to the problems with $D$. bruxellensis.

To detect sensu stricto spoilage yeasts, selective/differential media have been developed directed towards the most dangerous species-Z. bailii (Schuller et al. 2000) and D. bruxellensis (Rodrigues et al. 2001). Saccharomyces cerevisiae can be estimated indirectly by the difference between counting on general purpose media in the absence or presence of cycloheximide or of lysine (Heard and Fleet 1986). The presumptive results obtained with culture media could be further confirmed, if necessary, using biomarkers (biomolecule indicators) such as long-chain fatty acids (Malfeito-Ferreira et al. 1997) or molecular biological identification. Currently, yeast is identified by molecular methods, which, due to the degree of expertise and equipment required, are usually used by external laboratories and not by wineries. In rare and special situations, particularly commercial conflicts, fine molecular typing techniques, adequate to source tracking (Giudici and Pulvirenti 2002), may be used for forensic studies of wine contamination. Additionally, chemical indicators can also be used to monitor yeast activity in an easy and fast way. Among the molecules produced by yeasts, 4-ethylphenol is currently the most common indicator of $D$. bruxellensis activity and detection of this compound should be performed together with microbiological detection.

\section{References}

Agnolucci M, Vigentini I, Capurso G, Merico A, Tirelli A, Compagno C, Foschino R, Nuti M (2009) Genetic diversity and physiological traits of Brettanomyces bruxellensis strains isolated from Tuscan Sangiovese wines. Int J Food Microbiol 130:238-244

Barata A, Correia P, Nobre A, Malfeito-Ferreira M, Loureiro V (2006) Growth and 4-ethylphenol production by the yeast Pichia guilliermondii in grape juices. Am J Enol Vitic 57(2):133-138

Barata A, Caldeira J, Botellheiro R, Pagliara D, Malfeito-Ferreira M, Loureiro V (2008a) Survival patterns of Dekkera bruxellensis in wines and inhibitory effect of sulphur dioxide. Int $\mathrm{J}$ Food Microbiol 121:201-207

Barata A, Pagliara D, Piccininno T, Tarantino F, Ciardulli W, MalfeitoFerreira M, Loureiro V (2008b) The effect of sugar concentration and temperature on growth and volatile phenol production by Dekkera bruxellensis in wine. FEMS Yeast Res 8:1097-1102

Bell S-J, Henschke PA (2005) Implications of nitrogen nutrition for grapes, fermentation and wine. Aust $\mathrm{J}$ Grape Wine Res 11: 242-295

Bisson LF, Butzke CE (2000) Diagnosis and rectification of stuck and sluggish fermentations. Am J Enol Vitic 51:168-177

Blackburn C (ed) (2006) Food Spoilage Microorganisms. Woodhead, Cambridge

Boekhout T, Robert V (eds) (2003) Yeasts in Food: Beneficial and detrimental aspects. Behr, Hamburg

Caruso M, Fiore C, Contursi M, Salzano G, Paparella A, Romano P (2002) Formation of biogenic amines as criteria for the selection of wine yeast. World J Microbiol Biotechnol 18:159-163 
Chatonnet P, Dubourdieu D, Boidron JN (1995) The influence of Brettanomyces/Dekkera sp. yeasts and lactic acid bacteria on the ethylphenol content of red wines. Am J Enol Vitic 46:463-468

Chatonnet P, Viala C, Dubourdieu D (1997) Influence of polyphenolic components of red wines on the microbial synthesis of volatile phenols. Am J Enol Vitic 48:443-448

Connel L, Stender H, Edwards C (2002) Rapid detection and identification of Brettanomyces from winery air samples based on peptide nucleic acid analysis. Am J Enol Vitic 53:322-324

Costa A, Barata A, Malfeito-Ferreira M, Loureiro V (2008) Evaluation of the inhibitory effect of dimethyl dicarbonate (DMDC) against microorganisms associated with wine. Food Microbiol 25:422-427

Daudt CE, Ough CS (1980) Action of dimethyldicarbonate on various yeasts. Am J Enol Vitic 31:21-23

Deak T, Beuchat L (1996) Handbook of food spoilage yeasts. CRC, Boca Raton

Devéze M, Ribéreau-Gayon P (1977) Thermoresistance dês levures dans le vin application à la stabilisation biologique dês vins par la chaleur. Connaissance Vigne Vin 11:131-163

Dias L, Dias S, Sancho T, Stender H, Querol A, Malfeito-Ferreira M, Loureiro V (2003a) Identification of yeasts isolated from wine related environments and capable of producing 4-ethylphenol. Food Microbiol 20:567-574

Dias L, Pereira-da-Silva S, Tavares M, Malfeito-Ferreira M, Loureiro V (2003b) Factors affecting the production of 4-ethylphenol by the yeast Dekkera bruxellensis in enological conditions. Food Microbiol 20:377-384

Du Toit WJ, Lisjak K, Marais J, du Toit M (2006) The effect of microoxygenation on the phenolic composition, quality and aerobic wine-spoilage microorganisms of different South African red wines. S Afr J Enol Vitic 27:57-67

Dugelay I, Gunata Z, Sapis J-C, Baumes R, Bayonove C (1993) Role of cinnamoyl esterase activities from enzyme preparations on the formation of volatile phenols during winemaking. J Agric Food Chem 41:2092-2096

Farris G, Zara S, Pinna G, Budroni M (2002) Genetic aspects of flor yeasts Sardinian strains, a case of study. In: Ciani M (ed) Biodiversity and Biotechnology of wine yeasts. Research Signpost, Kerala, India, pp 71-83

Fleet G, Prakitchaiwattana C, Beh A, Heard G (2002) The yeast ecology of wine grapes. In: Ciani M (ed) Biodiversity and Botechnology of Wine Yeasts. Research Signpost, Kerala, India, pp 1-17

Fugelsang K, Edwards C (2007) Wine microbiology. Springer, Berlin

Giudici P, Pulvirenti A (2002) Molecular methods for identification of wine yeasts. In: Ciani M (ed) Biodiversity and biotechnology of wine yeasts. Research Signpost, Kerala, India, pp 35-52

Guerzoni E, Marchetti R (1987) Analysis of yeast flora associated with grape sour rot and of the chemical disease markers. Appl Environ Microbiol 53:571-576

Heard G, Fleet G (1986) Evaluation of selective media for enumeration of yeasts during wine fermentation. J Appl Bacteriol 60:477-481

Humbert C (1980) Thermolisation: its effects on wine Revue Française Oenologie 16:51-53

Ibeas JI, Lozano I, Perdigones F, Jiménez J (1996) Detection of Dekkera-Brettanomyces strains in sherry by a nested PCR method. Appl Environ Microbiol 62:998-1003

Ison R, Gutteridge C (1987) Determination of the carbonation tolerance of yeasts. Lett Appl Microbiol 5:11-13

Laureano P, D'Antuono I, Barata A, Malfeito-Ferreira M, Loureiro V (2004) Effect of different sanitation treatments on the population of Dekkera bruxellensis recovered from the wood of barrels (in Portuguese). Enologia 43(44):3-8
Loureiro V (1997) Spoilage yeasts in foods and beverages. Final Scientific report of the European AIR project CT93/830. DGXIIE-2, Bruxelles

Loureiro V, Malfeito-Ferreira M (2003) Spoilage yeasts in the wine industry. Int J Food Microbiol 86:23-50

Loureiro V, Malfeito-Ferreira M (2006) Spoilage activities of Dekkera/Brettanomyces spp. In: Blackburn C (ed) Food spoilage microorganisms. Woodhead, Cambridge, pp 354-398

Loureiro V, Querol A (1999) The prevalence and control of spoilage yeasts in foods and beverages. Trends Food Sci Technol 10 (11):356-365

Loureiro V, Malfeito-Ferreira M, Carreira A (2004) Detecting spoilage yeasts. In: Steele R (ed) Understanding and measuring the shelflife of food. Woodhead, Cambridge, pp 233-288

Malfeito-Ferreira M, Lopes J, Loureiro V (1990) Characterization of spoilage yeasts in Portuguese bottled dry white wines. In: Ribereau-Gayon P, Lonvaud A (eds) Actualités Oenologiques 89, Comptes rendus du 4eme Symposium International d'Oenologie. Bordeaux, Paris, pp 293-296

Malfeito-Ferreira M, Tareco M, Loureiro V (1997) Fatty acid profiling: a feasible typing system to trace yeast contaminations in wine bottling plants. Int J Food Microbiol 38:143-155

Malfeito-Ferreira M, Rodrigues N, Loureiro V (2001) The influence of oxygen on the "horse sweat taint" in red wines. Ital Food Beverage Technol 24:34-38

Malfeito-Ferreira M, Barata A, Loureiro V (2009) Wine spoilage by fungal metabolites. In: Polo C, Moreno-Arribas MV (eds) Wine chemistry and biochemistry, chap 11. Springer, New York, pp 615-645

Pitt J, Hocking A (1985) Fungi and food spoilage. Academic Press, Sydney

Querol A, Fleet G (eds) (2006) Yeasts in food and beverages. Springer, Berlin

Renouf V, Lonvaud-Funel A (2004) Racking are key stages for the microbial stabilization of wines. J Int Sci Vigne et du Vin $38: 219-224$

Renouf V, Lonvaud-Funel A (2007) Development of an enrichment medium to detect Dekkera/Brettanomyces bruxellensis, a spoilage wine yeast, on the surface of grape berries. Microbiol Res 162:154-157

Renouf V, Perello M-C, Revel G, Lonvaud-Funel A (2007) Survival of wine microorganisms in the bottle during storage. Am J Enol Vitic 58:379-386

Ribéreau-Gayon P, Dubourdieu D, Donèche B, Lonvaud A (2006) Handbook of enology (vols 1 and 2). The microbiology of wine and vinification. Wiley, Chichester

Rodrigues N, Gonçalves G, Pereira-da-Silva S, Malfeito-Ferreira M, Loureiro V (2001) Development and use of a new medium to detect yeasts of the genera Dekkera/Brettanomyces spp. J Appl Microbiol 90:588-599

Romano P (2005) Proprietà technologiche e di qualità delle specie di lieviti vinari. In: Vicenzini M, Romano P, Farris G (eds) Microbiologia del vino. Ambrosiana, Milano, pp 101-131

Schuller D, Côrte-Real M, Leão C (2000) A differential Medium for the Enumeration of the Spoilage Yeast Zygosaccharomyces bailii in Wine. J Food Prot 63:1570-1575

Stratford M (2006) Food and Beverage Spoilage Yeats. In: Querol A, Fleet $\mathrm{G}$ (eds) Yeasts in food and beverages. Springer, Berlin, pp 335-379

Suárez-Lepe J, Iñigo-Leal B (2004) Microbiología Enológica: Fundamentos de Vinificación (3rd edn). Mundi-Prensa, Madrid

Vigentini I, Romano A, Compagno C, Merico A, Molinari F, Tirelli A, Foschino R, Volonterio G (2008) Physiological and oenological traits of different Dekkera/Brettanomyces bruxellensis strains under wine-model conditions. FEMS Yeast Res 8:1087-1096 